Dalibor PETKOVIĆ, Ph.D

УДК 620.91

Faculty of Mechanical Engineering

- стручни рад -

University of Niš

\title{
ESTIMATION OF WIND FARM EFFICIENCY BY ANFIS STRATEGY
}

\begin{abstract}
A wind power plant which consists of a group of wind turbines at a specific location is also known as wind farm. The engineering planning of a wind farm generally includes critical decision-making, regarding the layout of the turbines in the wind farm, the number of wind turbines to be installed and the types of wind turbines to be installed. Two primary objectives of optimal wind farm planning are to minimize the cost of energy and to maximize the net energy production or to maximize wind farm efficiency. In the design process of a wind farm the aerodynamic interactions between the single turbines have become a field of major interest. The upwind turbines in a wind farm will affect the energy potential and inflow conditions for the downwind turbines. The flow field behind the first row turbines is characterized by a significant deficit in wind velocity and increased levels of turbulence intensity. Consequently, the downstream turbines in a wind farm cannot extract as much power from the wind as the first row turbines. Therefore modeling wind farm power production, cost, cost per power unit and efficiency is necessary to find optimal layout of the turbines in the wind farm. In this study, the adaptive neuro-fuzzy inference system (ANFIS) is designed and adapted to estimate wind farm efficiency according to turbines number in wind farm. The simulation results presented in this paper show the effectiveness of the developed method.
\end{abstract}

Key words: wind turbine, wind farm efficiency, power production, neurofuzzy, ANFIS.

\section{Introduction}

Wind energy is a promising renewable energy resource to help overcome global warming and environmental pollution from the use of fossil fuel. Renewable energy sources are the greatest resource for this purpose. The world's fastest growing renewable energy source is the wind energy [1]. Wind turbines are machines which convert the wind energy to the electricity [2]. Rapid advances in technical aspects and materials lead to an increase in size and output of the produced power [3]. A problem is in wind turbine sizing and choosing the optimal configuration of the turbine's parts [4]. Merely, by considering technical aspects, the best turbine is the most efficient one, which has the highest coefficient of energy or capacity factor [5]. However, taking economic aspects into account can modify the optimum size and design. Rotor radius, generator capacity and hub height are 
the most influential sizing parameters of the turbines. However, some limitations are available for their relationship and ratios. It may vary from site to the site and will be a function of the wind speed distribution at a given site.

Wind farms composed of large capacity wind turbines are main electrical energy sources. The modeling and simulation of the complete model of a wind farm with high number of wind turbines suppose the use of a high-order model and a long computation time if all the wind turbines are modeled. In order to reduce the model order and computation time, equivalent models was developed to represent the collective response of the wind [6]. These models are based on aggregating wind turbines into an equivalent wind turbine. As wind turbines become larger, wind farm layout design becomes more important. In [7] authors was enabled simultaneously optimization of the placement and the selection of turbines for commercial-scale wind farms that are subject to varying wind conditions. Among several wind farm layout design factors, wind turbine arrangement according to separation distance is one of the most critical factors for power output, annual energy production, availability, and life time of the wind turbine. Article [8] showed the effect of separation distance between two turbines and it was found to be crucial for the conceptual design of a wind farm layout. Therefore, during wind farm layout design, separation distance and interaction between wind turbines must be carefully considered because they are directly connected to the initial investment cost, payback period and economic efficiency. In article [9] the characteristics of turbine spacing for optimal wind farm efficiency were investigated using combined numerical models. The results showed that the spacing between the first and the second turbines had the importance to the entire farm's efficiency. In [10] authors focused on the site specific optimization of wind turbines by minimizing cost of electricity production. The study utilizes the complete and comprehensive capital cost model for wind turbines plus technical aerodynamic model based on blade element momentum theory with twenty blade elements. In article [11] was measured the productive efficiency of a group of wind farms during the period 2001-2004 using the frontier methods Data Envelopment Analysis (DEA) and Stochastic Frontier Analysis (SFA).

The objective of the present study is to analyze relationship between wind farm efficiency, power production, cost, cost per power unit and the number of wind turbines in wind farm. Aiming at optimizing such systems to ensure optimal functioning of the wind farm, new techniques are used today such as the fuzzy logic (FL) [12], artificial neural network (ANN) [13] and neuro-fuzzy [14].

Artificial neural networks are adaptable demonstrating apparatuses with proficiencies of taking in the numerical mapping between data and yield variables of nonlinear frameworks. A standout amongst the most compelling sorts of neural system framework is adaptive neuro-fuzzy inference system (ANFIS) [15]. ANFIS indicates great taking in and expectation competencies, which makes it a proficient device to manage experienced vulnerabilities in any framework. ANFIS, as a hybrid intelligent system that enhances the ability to automatically learn and adapt, was used by researchers in various engineering systems. 
The key objective of this examination is to create an ANFIS for estimation of the wind farm efficiency. An endeavor is made to recover association between wind farm efficiency in regard to number of wind turbines. The training experimental data will be extracted by an analytical, closed-form wake model [16] which quantifies the aerodynamic interaction between turbines.

\section{Wind Farm Efficiency Model}

Analytical wake model named as Jensen's wake model [16] is chosen in the study, since energy is considered as saved inside the wake by this model. The wake grows straightly with downstream separation. In this manner, this model is suitable for the far wake locale. The wake has a sweep, at the turbine which is equivalent to the turbine range $R_{r}$ while, $R_{1}$ is the radius of the wake in the model. $R_{1}$ is considered as radius of the downstream wake; the relationship between $R_{1}$ and $X$ is that downstream distance when the wake spreads downstream the radius $R_{1}$; that increases linearly proportional, $X$. The wake extends directly with downstream separation, as expressed in Jensen's model as demonstrated in Figure 1.

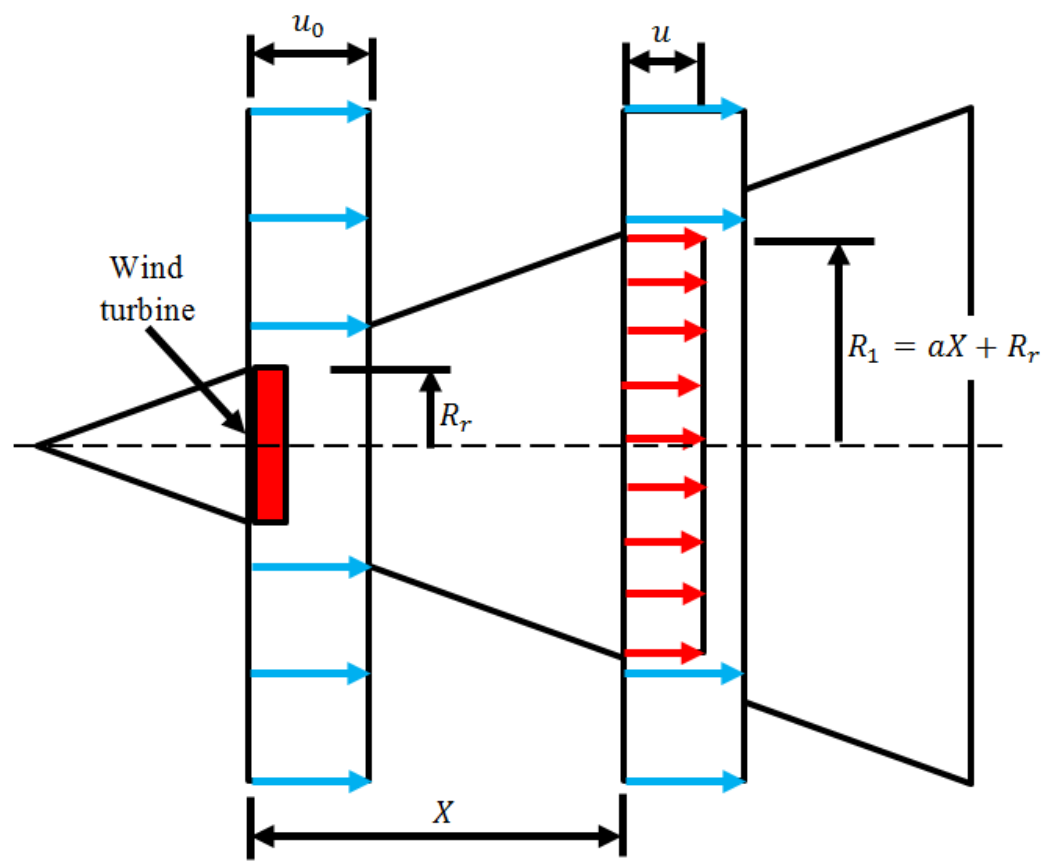

Figure 1: Schematic of wake model

Following equation [38] was used to determine the wind speed after wind turbine rotor as it shown in Figure 1: 


$$
u=u_{0} *\left(1-\frac{2 a}{1+\sigma\left(\frac{x}{\left(R_{r} \sqrt{\frac{1-a}{1-2 a}}\right)}\right)^{2}}\right)
$$

In the equation (1) we have:

- $u_{0}$ is the mean wind rate or which might be clarified as the free stream wind speed and in this study was utilized $u_{0}=12 \mathrm{~m} / \mathrm{s}$,

- axial induction factor is denoted by $a$ which can be calculated from the $C_{T}$, thrust coefficient. This can be determined from the equation:

$$
C_{T}=4 a(1-a)
$$

- $X$ is the distance downstream of the turbine, while $R_{1}$ is related with $R_{r}$ as represented using following equation:

$$
R_{1}=R_{r} \sqrt{\frac{1-a}{1-2 a}}
$$

- $\sigma$ is the entertainment constant and by using the following equation:

$$
\sigma=\frac{0.5}{\ln \frac{z}{z_{0}}}
$$

In the above equation, $z$ is used to denote the hub height and roughness of the surface is denoted by $z_{0}$. The value for surface roughness varies from field to field. For plain terrains the value for $z_{0}=0.3$.

The accessible wind force could be computed by utilizing the accompanying comparison:

$$
P_{a}=\frac{1}{2} \mathrm{c} A u^{3}
$$

If the power production from each wind turbine contains the efficiency 3 of wind turbine then the following equation for the energy or power generated from a wind turbine can be used:

$$
P_{p}=3 \frac{1}{2} \mathrm{c} A u^{3}
$$

If that the efficiency of wind turbines is equal to $40 \%$, then the equation will be:

$$
P_{p}=\frac{40}{100} \frac{1}{2} \mathrm{cAu} u^{3}
$$

In the above equation $A$ represents cover surface of the turbine blades during rotation and it is $A=\mathrm{p} 40^{2}$ since the used rotor radius in the study is $R_{r}=$ $40 \mathrm{~m}$, and $\mathrm{c}=1.2$. The following equation will be derived:

$$
P_{p}=301 u^{3} W(5)
$$

For the calculation of power into $\mathrm{kW}$ we have the following equation:

$$
P_{p}=0.3 u^{3} k W(6)
$$


Effectiveness is a term which is utilized for the measure of vitality concentrated as a piece of the aggregate vitality accessible. The effectiveness might be ascertained from the accompanying comparison:

$$
\begin{aligned}
& E=\frac{\sum_{i=1}^{N_{t}} 0.3 \times u_{i}^{3}}{N_{t}\left(0.3 \times u_{0}^{3}\right)}(7) \\
& E=\frac{P_{t}}{N_{t}\left(0.3 \times u_{0}^{3}\right)}(8)
\end{aligned}
$$

where $N_{t}$ represents the turbines number in wind farm, $P_{t}$ is total delivered power from all wind turbines in wind farm.

The expense demonstrate that is utilized as a part of the present study is the same as that was utilized within prior studies $[40,41]$. This model encourages a decrease of $1 / 3$ in expense for every new wind turbine establishment. In this way, it might be said that this expense model is a capacity of number of turbines. From the above view the aggregate expense could be explained utilizing the accompanying comparison:

$$
C=N_{t}\left[\frac{2}{3}+\frac{1}{3} e^{-0.00174 * N_{t}^{2}}\right]
$$

where $N_{t}$ represents the number of turbines in wind farm.

It is useful to analyze also the cost per power unit (CPPU) if only one wind turbine is installed in wind farm and it can be defined as following:

$$
C P P U=\frac{C}{P_{t}}(10)
$$

In this study the used values are as under:

$$
\begin{gathered}
X=200 \mathrm{~m} \\
R_{r}=40 \mathrm{~m} \\
u_{0}=12 \mathrm{~m} / \mathrm{s} \\
a=0.326795 \\
\text { б=0.09437 }
\end{gathered}
$$

\section{Adaptive neuro-fuzzy inference application}

An ANFIS model was established in this study to estimate the efficiency, cost, cost per power unit and power production in wind farm in relation to number of turbines in the wind farm. For the present study equations (1) to (10) were used to extract training experimental data for the ANFIS network modeling. One 50\% of the extracted data were utilized for preparing while the other half is utilized for checking and acceptance of the model. With a legitimate preparing plan and fine separated information sets, ANFIS can efficiency, cost, cost per power unit and power production in wind farm quite accurately since it learns from training data. This measurement-free architecture also makes it immediately available for operation once they are trained.

There were three membership functions on each input. In this study bellshaped membership functions were chosen with maximum equal to 1 and minimum equal to 0. Figure 2 shows an ANFIS model with three inputs. 
Layer 1

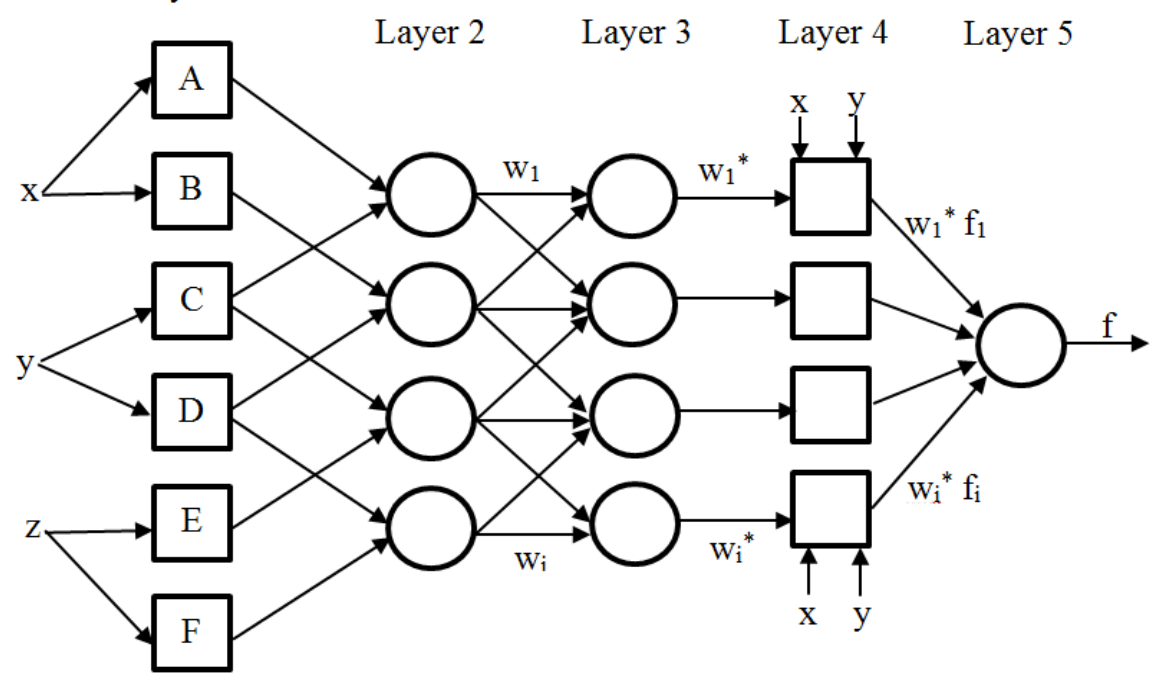

Figure 2: ANFIS structure

In this work, the first-order Sugeno model with two inputs and fuzzy IFTHEN runs of Takagi and Sugeno's sort was utilized:

$$
\text { if } x \text { is } A \text { and } y \text { is } C \text { and } z \text { is } E \text { then } f_{1}=p_{1} x+q_{1} y+r_{1} z+t(11)
$$

The first layer has input variables i.e. membership functions (MFs), input 1, input 2 and input 3. This layer simply supplies the data qualities to the following layer. At the beginning there are three ANFIS networks which estimates power production, cost and cost per power unit of wind farm in depend on number of wind turbines in the wind farm. The outputs of the three ANFIS networks represent inputs to the new ANFIS network with three inputs (Figure 2). The input 1: $\mathrm{x}$ is power production, input 2: $\mathrm{y}$ is cost per power unit and input $3: \mathrm{z}$ is total cost of the wind farm. In the first layer every node is an adaptive node with a node function

$$
O=\mathrm{M}(x, y, z),
$$

where $\mathrm{M}(x, y, z)_{i}$ are membership functions.

Bell-shaped membership functions (3) with maximum 1 and minimum 0 was chosen in this study:

$$
f(x ; a, b, c)=\frac{1}{1+\left(\frac{x-c}{a}\right)^{2 b}}
$$

where the bell-shaped function depends on three parameters $a, b$ and $c$. The parameter $b$ is usually positive. The parameter $c$ located the center of the curve as it is shown in Figure 3. 


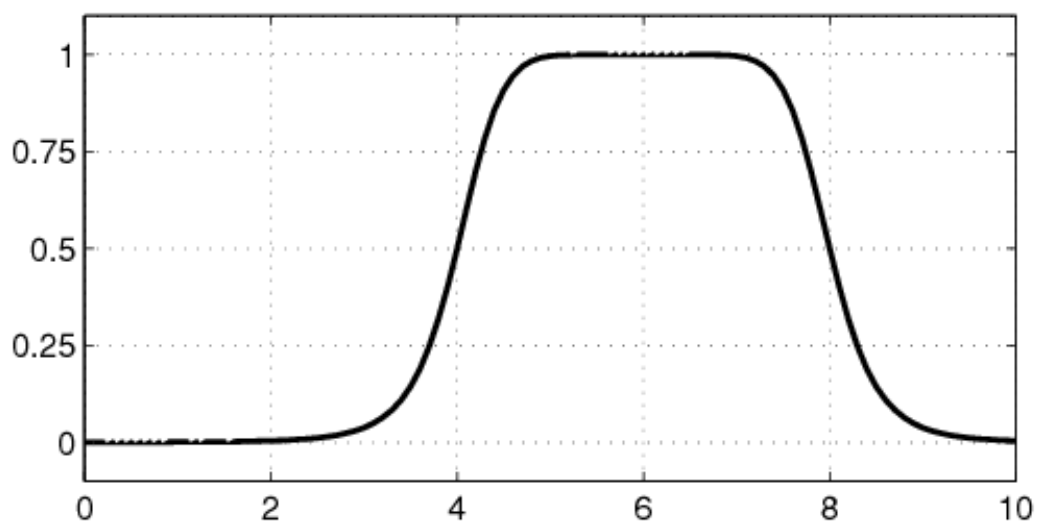

Figure 3: Bell-shaped membership function $(a=2, b=4, c=6)$

The second layer (participation layer) checks for the weights of every Mfs. It accepts the info values from the first layer and goes about as Mfs to speak to the fuzzy sets of the separate information variables. Each hub in the second layer is non-versatile and this layer reproduces the approaching signs and sends the item out like

$$
w_{i}=\mathrm{M}(x)_{i} * \mathrm{M}(x)_{i+1}
$$

Every hub yield speaks to the terminating quality of a standard or weight.

The third layer is known as the standard layer. Every hub (every neuron) in this layer performs the precondition matching of the fuzzy tenets, i.e. they register the initiation level of each one lead, the amount of layers being equivalent to the amount of fuzzy guidelines. Every hub of these layers figures the weights which are standardized. The third layer is likewise non-versatile and each hub figures the proportion of the guideline's terminating quality to the total of all standards' terminating qualities like

$$
\begin{gathered}
w_{i}^{*}=\frac{w_{i}}{w_{1}+w_{2}} \\
i=1,2 .
\end{gathered}
$$

The outputs of this layer are called normalized firing strenghts or normalized weights.

The fourth layer is called the defuzzification layer and it provides the output values resulting from the inference of rules. Every node in the fourth layer is an adaptive node with node function

$$
O_{i}^{4}=w_{i}^{*} x f=w_{i}^{*}\left(p_{i} x+q_{i} y+r_{i}\right)
$$

where $\left\{p_{i}, q_{i}, r\right\}$ is the consequent parameters.

The fifth layer is known as the yield layer which totals up all the inputs hailing from the fourth layer and converts the fuzzy characterization results into a fresh (paired). The single hub in the fifth layer is not versatile and this hub figures the general yield as the summation of all approaching indicators 


$$
O_{i}^{5}=\sum_{i} w_{i}^{*} x f=\frac{\sum_{i} w_{i} f}{\sum_{i} w_{i}}
$$

The hybrid learning algorithms were used to identify the parameters in the ANFIS architectures.

\section{Results}

The proposed ANFIS structure has three inputs as it shown in Figure 4. There are three bell-shaped membership functions for each input. The three inputs are:

1. input1: Wind farm power production,

2. input2: Wind farm cost per power unit,

3. input3: Wind farm cost.

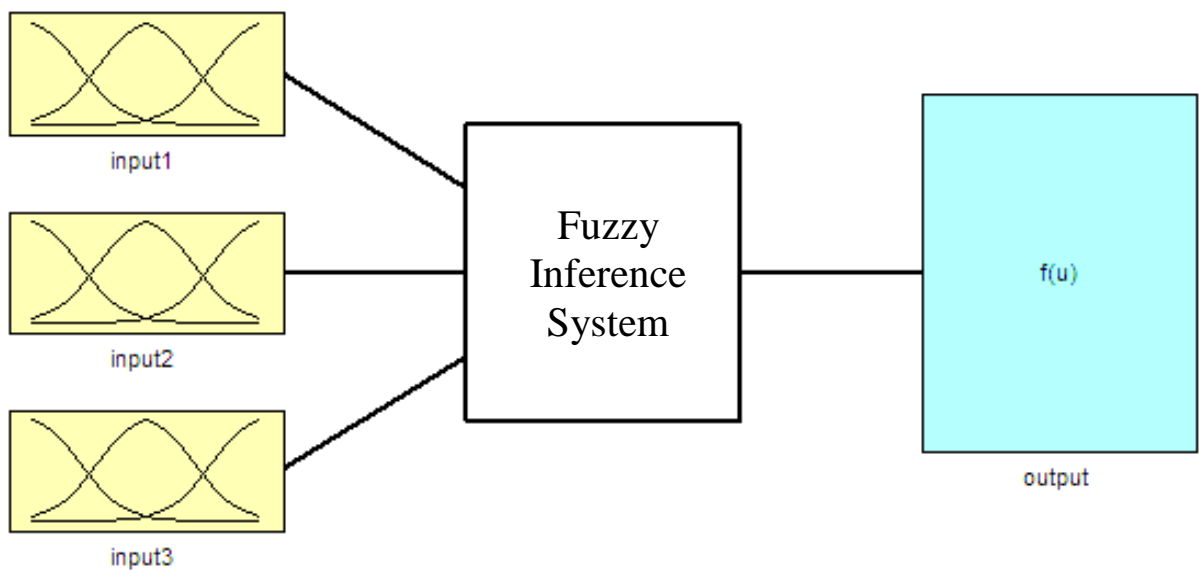

Figure 4: Fuzzy inference system with three inputs

Since Bell-shaped membership function was used for the fuzzy regression of the training data it is necessary to determine the parameters $(a, b, c)$ of the function as it depicted in the equation (12). After training procedure of the proposed ANFIS network the optimal parameter of the bell-shaped function were obtained. The ANFIS RMSE after training procedure was 0.0040505 . The training procedure lasted 1000 epochs or 3 hours.

Figure 5 shows ANFIS decision surface for power production $(\mathrm{kW})$ in wind farm in depend on the number of wind turbines. It is clear that the power production increases almost linearly in relation to the number of wind turbines increasing. 


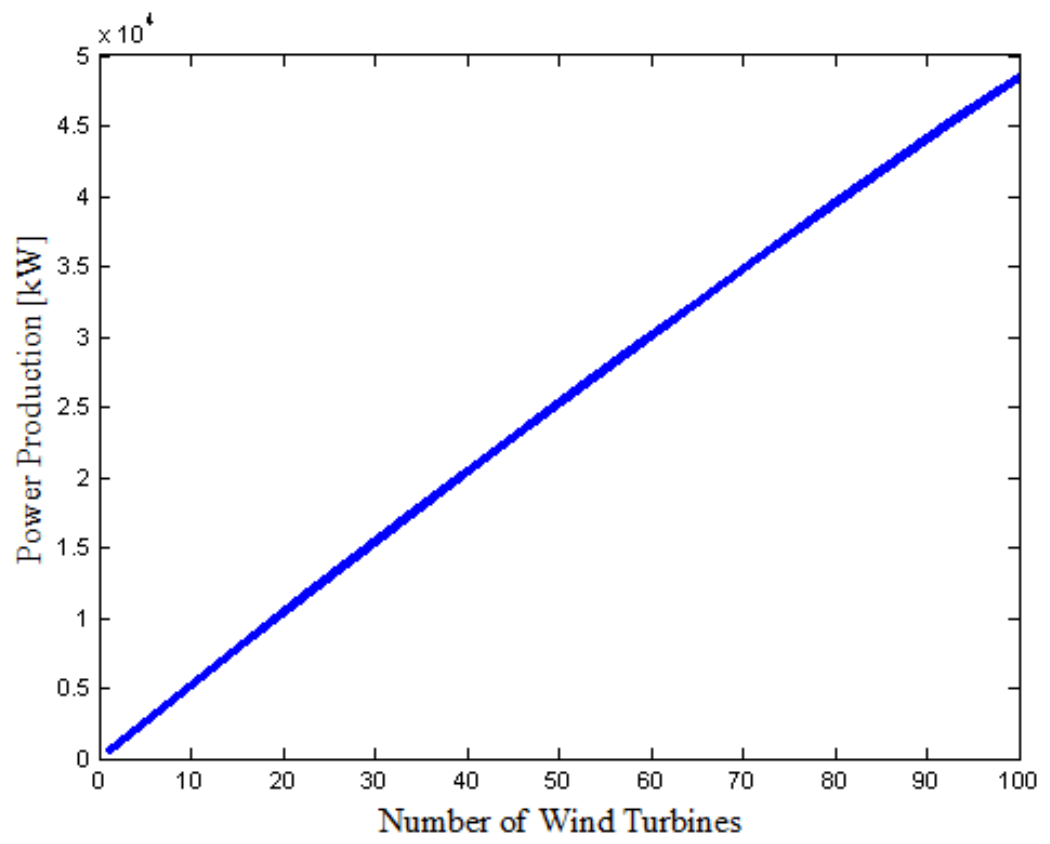

Figure 5: ANFIS predicted relationship between the number of wind turbines and produced power in wind farm

Figure 6 depicts ANFIS predicted cost model for increasing of wind turbines in wind farm. From this figure it is clear that the cost is reduced for $1 / 3$ after $10^{\text {th }}$ wind turbine.

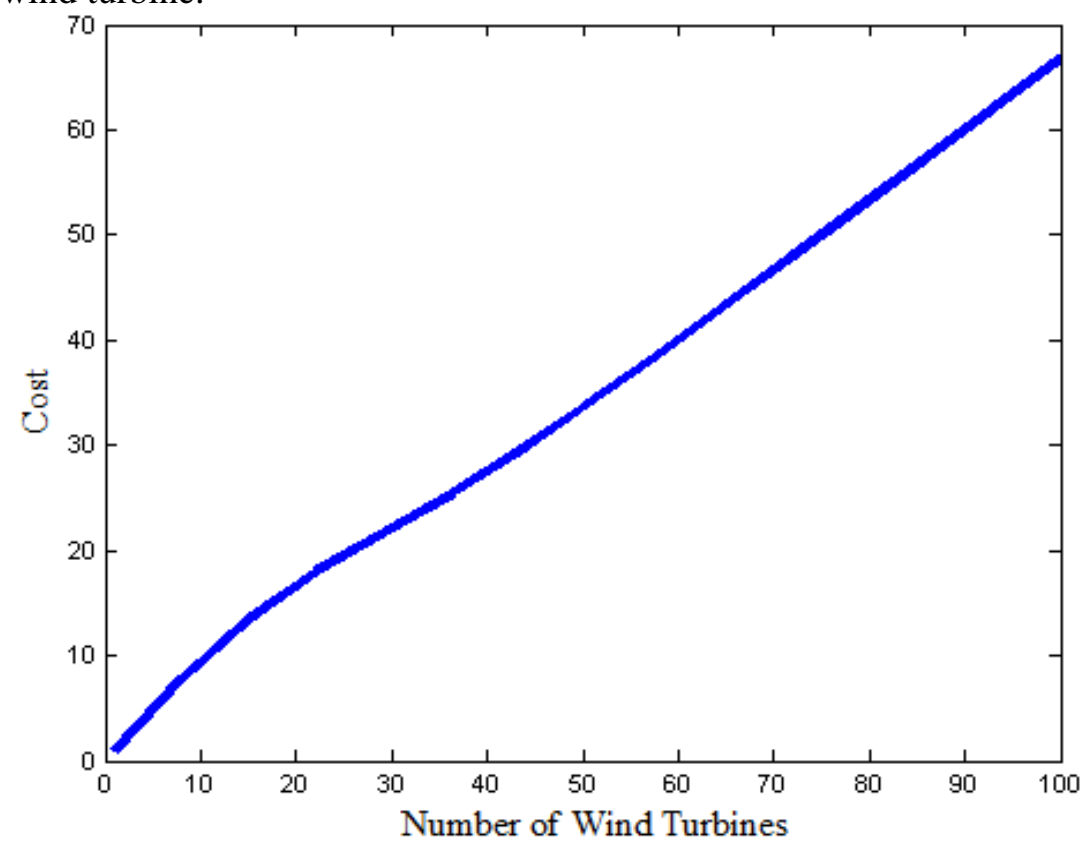

Figure 6: ANFIS predicted relationship between the number of wind turbines and total cost 
It is interesting to analyze cost when one wind turbine is installed in the wind farm or cost per power unit. The graph in Figure 7 depicts cost per power unit in function of number of wind turbines in wind farm. It is clear that the least cost could be attained if the ideal force preparation is procured from a specific number of wind turbines. The chart portrays that the goal capacity (10) gives the diminishment in expense in the way that as the amount of wind turbines expands, there is a lessening in the normal expense of one wind turbine. Thus, the expense is beginning to decline.

After analyzing the ANFIS model when the number of wind turbines reaches to 52, it is going to be optimized. For 53 number of wind turbines the ANFIS found 0.001329007 cost per power unit and $26690 \mathrm{~kW}$ power production. For 54 number of wind turbines the ANFIS found 0.001329019 cost per power unit and $27170 \mathrm{~kW}$ power production. ANFIS model shows when the $55^{\text {th }}$ wind turbine is added, the cost per unit power increases and it reaches 0.001329215 . Hence, the most optimized cost per power unit is for 53 installed turbines. Table 1 shows results overview for two characteristic wind farms.

Table 1. The ANFIS results for two characteristic wind farms

\begin{tabular}{|c|c|c|c|}
\hline Wind turbines \# & ANFIS RMSE & $\begin{array}{c}\text { Wind farm power } \\
\text { production }\end{array}$ & $\begin{array}{c}\text { Wind farm effi- } \\
\text { ciency }\end{array}$ \\
\hline 53 & 0.001329007 & $26690 \mathrm{~kW}$ & $97.14 \%$ \\
\hline 54 & 0.001329019 & $27170 \mathrm{~kW}$ & $97.1 \%$ \\
\hline
\end{tabular}

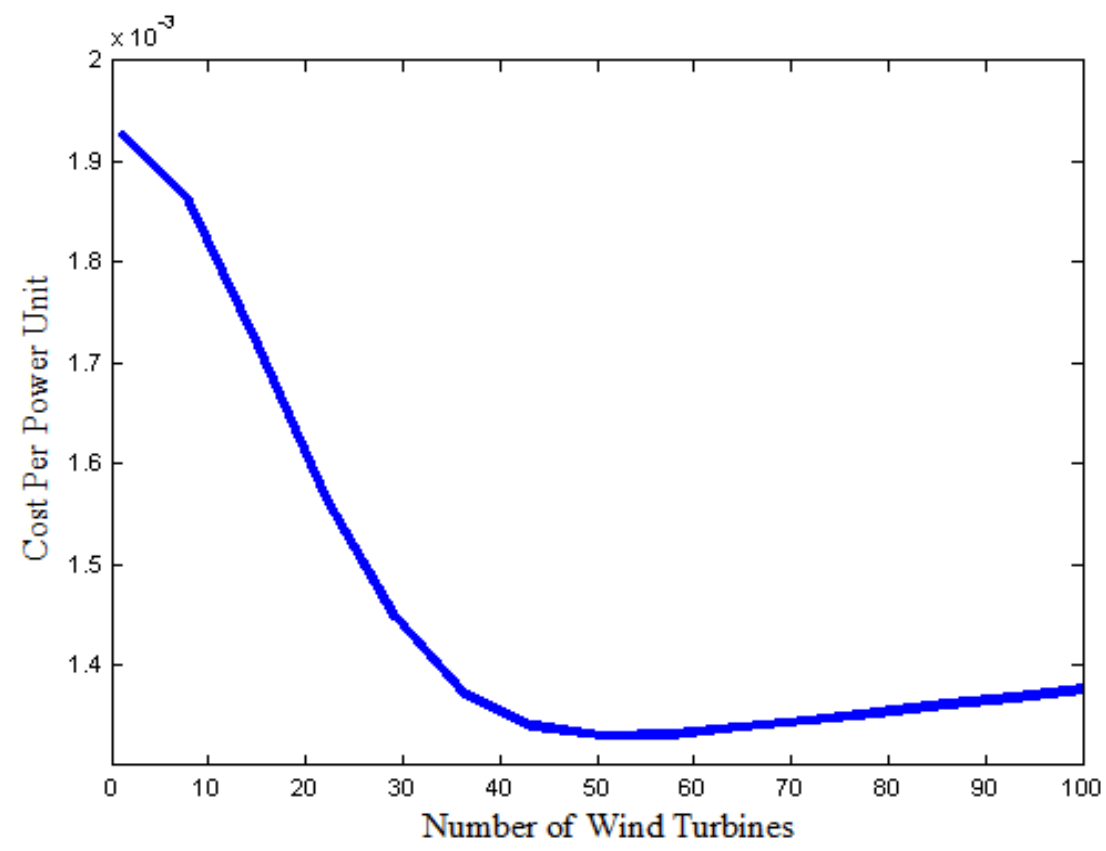

Figure 7: ANFIS predicted relationship between the number of wind turbines and cost per power unit 
Figure 8, Figure 9 and Figure 10 shows ANFIS predicted relationships between wind farm power production, total cost, cost per power unit and wind farm efficiency. For wind farm with 53 turbines the efficiency is $97.14 \%$, and for wind farm with 54 the efficiency is $97.1 \%$.

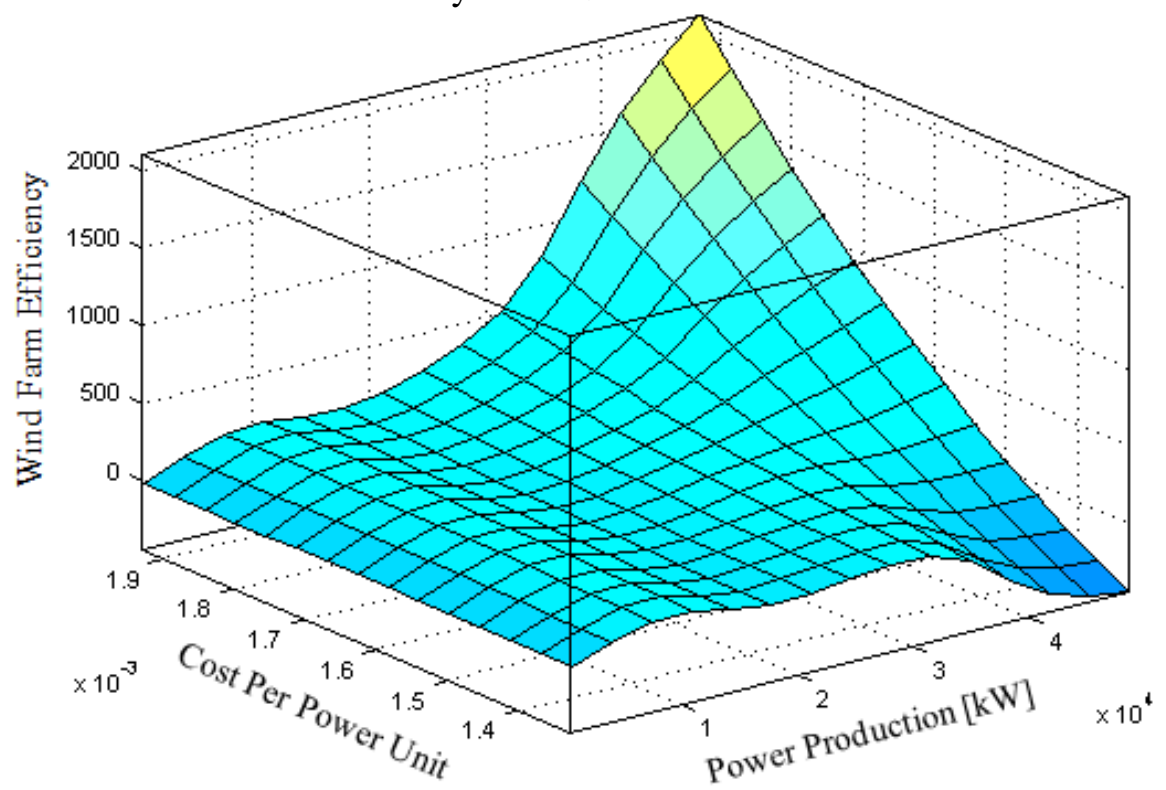

Figure 8: ANFIS predicted relationship between wind farm power production, cost per power unit and wind farm efficiency

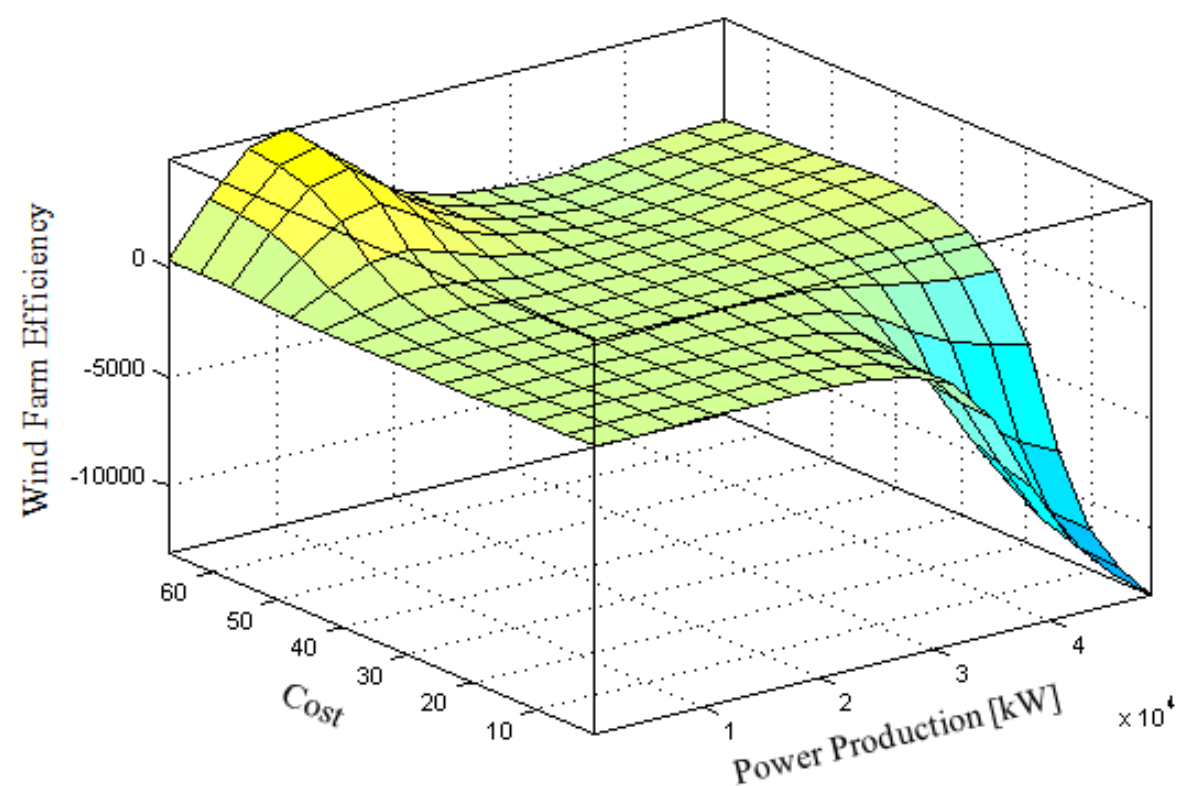

Figure 9: ANFIS predicted relationship between wind farm power production, cost and wind farm efficiency 


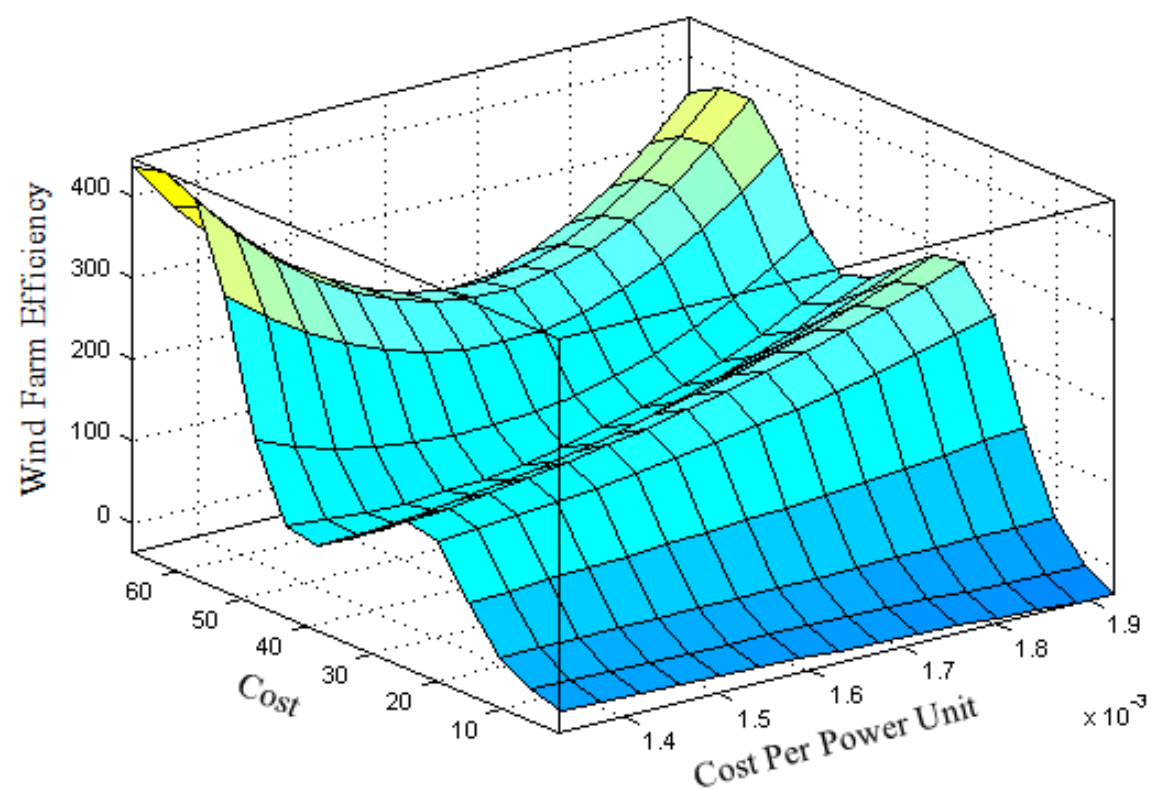

Figure 10: ANFIS predicted relationship between wind farm cost per power unit, cost and wind farm efficiency

The wind farm power production, cost per power unit and total cost as function of the number of wind turbines is implemented in MATLAB Simulink block diagram as it shown in Figure 11. This approach is very usefull for fast estimation of the main parameters of wind farms according to the number of installed wind turbines. Here can be seen results for wind farm wind number of wind turbines 53.

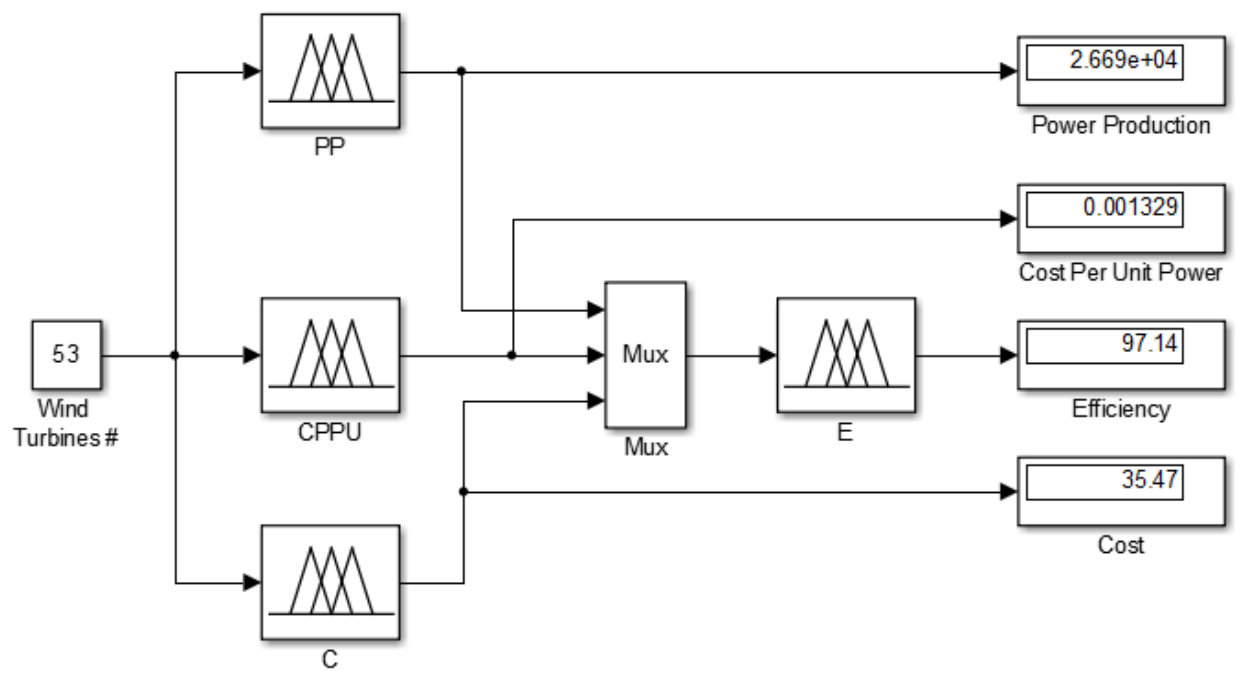

Figure 11: Simulink block diagram for estimation of the wind farm power production, cost per power unit, total cost and efficiency 


\section{Conclusion}

As a result of increasing wind farms penetration in power systems, the wind farms begin to influence power system, and thus the analyzing of wind farms has become an interesting research topic. The optimal placement of wind turbines in a wind farm and the optimal number of wind turbines will maximize the total wind energy extraction efficiency of a wind farm. In a wind farm, wind turbines have interactions between them. The effect of these interactions is characterized by wind velocity deficit, which leads to less power available for the downstream turbines.

In this investigation a systematic approach to achieving optimal number of wind turbines in wind farm by means of ANFIS strategy was investigated. A Simulink model was developed in MATLAB with the ANFIS network for the wind farm power production, total cost, cost per power unit and wind farm efficiency estimation. The principle point of interest of planning the ANFIS coordination plan is to estimate wind farm efficiency as one very important parameter for overall produced energy according to number of wind turbines.

The fundamental favorable circumstances of the ANFIS plan are: computationally proficient, well-versatile with enhancement and versatile procedures. The created procedure is straightforward, as well as solid and may be not difficult to execute continuously requisitions utilizing some interfacing cards like the dSPACE, information procurement cards, NI cards, and so forth for control of different parameters. This can additionally be consolidated with master frameworks and unpleasant sets for different requisitions. ANFIS can likewise be utilized with frameworks taking care of more perplexing parameters. An alternate playing point of ANFIS is its speed of operation, which is much quicker than in other control procedures; the monotonous assignment of preparing participation capacities is carried out in ANFIS. A standout amongst the most essential gimmicks of the proposed ANFIS system is recognizable proof and estimation of the wind ranch productivity, power generation, aggregate cost and expense for every force unit.

\section{References}

[1] Yang Z., Sarkar P., Hu H. (2011): An Experimental Investigation on the Wake Characteristics of a Wind Turbine in an Atmospheric Boundary Layer Wind, 29th AIAA Applied Aerodynamics Conference. 27 - 30 June 2011, Honolulu, Hawaii, 1-18.

[2] Grant I., Mo M., Pan X., Parkin P., Powell J., Reinecke H., Shuang K., Coton F., Lee D. (2011): An experimental and numerical study of the vortex laments in the wake of an operational, horizontal-axis, wind turbine, Journal of Wind Engineering and Industrial Aerodynamics. 85, 177-189.

[3] Wagner M., Day J., Neumann F. (2013): A fast and effective local search algorithm for optimizing the placement of wind turbines, Renewable Energy. 51, 64-70. 
[4] Ituarte-Villarreal C. M., Espiritu J. F. (2011): Optimization of wind turbine placement using a viral based optimization algorithm, Procedia Computer Science, $6469-474$.

[5] Bououden S., Chadli M., Filali S., El Hajjaji A. (2012): Fuzzy model based multivariable predictive control of a variable speed wind turbine: LMI approach, Renewable Energy. 37, 434-439.

[6] Meharrar A., Tioursi M., Hatti M., Boudghène Stambouli A. (2011): A variable speed wind generator maximum power tracking based on adaptative neurofuzzy inference system, Expert Systems with Applications. 38, 7659-7664.

[7] Fernandez L.M., Jurado F., Saenz J.R. (2008): Aggregated dynamic model for wind farms with doubly fed induction generator wind turbines, Renewable Energy. 33, 129-140.

[8] Chowdhury S., Zhang J., Messac A., Castillo L. (2013): Optimizing the arrangement and the selection of turbines for wind farms subject to varying wind conditions, Renewable Energy. 52, 273-282.

[9] Choi N.J., Nam S.H., Jeong J.H., Kim K.C. (2013): Numerical study on the horizontal axis turbines arrangement in a wind farm: Effect of separation distance on the turbine aerodynamic power output, Journal of Wind Engineering and Industrial Aerodynamics. 117, 11-17.

[10] Krokoszinski H.J. (2003): Efficiency and effectiveness of wind farms-keys to cost optimized operation and maintenance, Renewable Energy. 28, 2165-2178.

[11] Mirghaed M.R., Roshandel R. (2013): Site specific optimization of wind turbines energy cost: Iterative approach, Energy Conversion and Management. 73 167-175.

[12] Qi Y., Meng Q. (2012): The Application of Fuzzy PID Control in Pitch Wind Turbine, Energy Procedia. 16, 1635-1641.

[13] Wua S., Wanga Y., Cheng S. (2013): Extreme learning machine based wind speed estimation and sensorless control for wind turbine power generation system, Neurocomputing. 102, 163-175.

[14] Mohandes M., Rehman S., Rahman S.M. (2011): Estimation of wind speed profile using adaptive neuro-fuzzy inference system (ANFIS), Applied Energy. 88, 4024-4032.

[15] Jang J.S.R. (1993): ANFIS: Adaptive-Network-based Fuzzy Inference Systems, IEEE Transaction On Systems, Man, and Cybernetics. 23: 665-685.

[16] Jensen N.O. (1983): A note on wind generator interaction, Roskilde, Denmark: Riso National Laboratory. No. 2411.

Др Далибор Петковић

\section{ПРОЦЕНА ЕФИКАСНОСТИ ФАРМЕ ВЕТРА КОРИШЋЕЊЕМ АНФИС СТРАТЕГИЈЕ}

Сажетак: Електрана на ветар која се састоји од више турбина на ветар на одређеној локачији, такође је позната под називом „ффарма ветра“. Инжењерско планирање фарме ветра генерално укључује доношење одлука о распореду турбина на фарми ветра, броју турбина на ветар које треба поставити и врсти турбина на ветар које ће бити постављене. Два примарна ичиља 
оптималног планирања фарме ветра су да се ито више смањи трошак производюе енергије и да се што више повећа нето производюа енергије или да се ито више повећа ефикасност фарме ветра. У процесу дизајнирања фарме ветра аеродинамичке интеракције између јединачних турбина су постале поље главног интересовања. , Upwind“ турбине (окренуте ветру при раду) на фарми ветра ће утицати на енергетски потениијал и услове дотока код ,, downwind“ турбина (окренутих од ветра при раду). Поље протока иза првог реда турбина карактерише значајно сманене у брзини ветра и повећани нивои интензитета турбулениије. Дакле, турбине у наставку на фарми ветра не могу да извуку толико снаге од ветра као турбине у првом реду. Стога, неопходно је дизајнирати производюу енергије фарме ветра, трошкове, трошак по енергетској јединици и ефикасност да би се пронамао оптимални распоред турбина на фарми ветра. У овој студији, адаптивна мрежа заснована на систему фази закључивань (the adaptive neuro-fuzzy inference system (ANFIS)) (адаптивна неуронска мрежа) је дизајнирана и прилагођена да изврии прорачун ефикасности фарме ветра према броју турбина на фарми ветра. Резултати симулащије представљени у овом раду показују ефикасност развијене методе.

Кључне речи: турбина на ветар, ефикасност фарме ветра, производюь анергије, nеuro-fuzzy, ANFIS.

Примљено: 16. 10. 2015. године.

Одобрено за штампу: 21. 1. 2016. године. 